\title{
Oleic acid induces smooth muscle foam cell formation and enhances atherosclerotic lesion development via CD36
}

\author{
Shuangtao $\mathrm{Ma}^{\dagger}$, Dachun Yang ${ }^{\dagger}$, De Li, Bing Tang and Yongjian Yang ${ }^{*}$
}

\begin{abstract}
Background: Elevated plasma free fatty acid (FFA) levels have been linked to the development of atherosclerosis. However, how FFA causes atherosclerosis has not been determined. Because fatty acid translocase (FAT/CD36) is responsible for the uptake of FFA, we hypothesized that the atherogenic effects of FFA may be mediated via CD36.

Results: We tested this hypothesis using cultured rat aortic smooth muscle cells (SMCs) treated with oleic acid (OA). We found that OA induces lipid accumulation in SMCs in a dose dependent manner. Rat aortic SMCs treated for 48 hours with OA ( $250 \mu \mathrm{mol} / \mathrm{L}$ ) became foam cells based on morphological (Oil Red O staining) and biochemical (5 times increase in cellular triglyceride) criteria. Moreover, specific inhibition of CD36 by sulfo-N-succinimidyl oleate significantly attenuated OA induced lipid accumulation and foam cell formation. To confirm these results in vivo, we used ApoEdeficient mice fed with normal chow (NC), OA diet, NC plus lipolysis inhibitor acipimox or OA plus acipimox. OA-fed mice showed increased plasma FFA levels and enhanced atherosclerotic lesions in the aortic sinus compared to the NC group (both $p<0.01$ ). This effect was partially reversed by acipimox (lesion area: OA: $3.09 \pm 0.10 \times 10^{5} \mu \mathrm{m}^{2} \mathrm{vs}$. OA plus acipimox: $2.60 \pm 0.10 \times 10^{5} \mu^{2}, p<0.05$; FFA: OA: $0.91 \pm 0.03 \mathrm{mmol} / \mathrm{L}$ vs. OA plus acipimox: $0.78 \pm 0.03 \mathrm{mmol} / \mathrm{L}$, $p<0.05)$.

Conclusions: These findings suggest that $O A$ induces smooth muscle foam cell formation and enhances atherosclerotic lesions in part though CD36. Furthermore, these findings provide a novel model for the investigation of atherosclerosis.
\end{abstract}

\section{Background}

Foam cell formation is an important process in the development of atherosclerosis [1]. Foam cells have been demonstrated to be of either macrophage or smooth muscle cell (SMC) origin [2]. Circulating cholesterol has been traditionally recognized as an important risk factor of atherosclerosis. Macrophages can easily be induced to transform into foam cells by loading modified low density lipoprotein (LDL) cholesterol donors, including ox-LDL. However, the method that induces SMC to form foam cell through cholesterol loading has been challenged [3]. Attempts to extensively load vascular SMC with cholesterol have been largely unsuccessful [4-6]. This phenomenon suggests that there is another mechanism underlying

\footnotetext{
* Correspondence: yongjiany@yahoo.cn

+ Contributed equally

Department of Cardiology, General Hospital of PLA Chengdu Military Area Command, Chengdu 610083, PR China
}

the formation of SMC-derived foam cells. To date, the mechanism by which vascular SMC could accumulate large stores of lipids remains elusive.

Cholesterol and triglyceride are the major components of atherosclerotic plaques. Cholesterol esters and triglycerides all contain fatty acids. Pilz et al [7] have reported that free fatty acids (FFA) are independently associated with cardiovascular mortality in subjects with coronary artery disease, indicating that FFA might promote the development of atherosclerosis. Although FFA is linked to the pathogenesis of atherosclerosis [8], the mechanism by which FFA regulates the development of atherosclerosis is still unknown [9].

Several studies have demonstrated that FFA might cause a significant amount of lipid accumulated in both hepatic [10] and skeletal muscle cells [11]. Fatty acid translocase (FAT/CD36), originally identified as glycoprotein IV on platelets, is an $88-\mathrm{kDa}$ integral membrane 
protein that has multiple legends and is widely expressed in different cell types [12], including vascular SMCs [13]. Recent studies have shown that CD36 is also a crucial transporter for FFA [14]. Previous observations have suggested that CD36 deficiency may provide a more atherogenic environment to accelerate the development of atherosclerosis [13], causing a significant increase in fasting levels of FFA.

Therefore, we hypothesized that FFA might induce smooth muscle foam cell formation and enhance atherosclerotic lesion development via CD36. In the present study, we present a model of smooth muscle foam cell formation. We propose that elevated levels of FFA could increase the uptake of fatty acids in vascular SMC via CD36 and subsequently induce the formation of smooth muscle foam cells and accelerate the development of atherosclerotic lesions in ApoE-deficient $\left(\mathrm{ApoE}^{-/-}\right)$mice.

\section{Results}

Induction of vascular smooth muscle foam cell formation by oleic acid

We examined lipid accumulation by using Oil Red $\mathrm{O}$ staining (Figure 1A). After incubation with oleic acid (OA) for 48 hours, rat SMC assumed the morphological appearance of foam cells with significant lipid accumulation; in contrast, no lipid droplets were found in the untreated cells. The visual abundance of lipid droplets was grossly correlated with $\mathrm{OA}$ concentration in the treatment. Measurement of triglyceride and cholesterol esters confirmed cellular accumulation of lipids. Incubation with $\mathrm{OA}$ increased intracellular triglyceride levels in a dose-dependent manner $(p<0.01$, Figure $1 \mathrm{~B})$. However, intracellular cholesterol esters were slightly, but not significantly, increased by incubation with $\mathrm{OA}$ at a concentration of $100 \mu \mathrm{mol} / \mathrm{L}$ and were not further increased by $\mathrm{OA}$ at higher concentrations (Figure $1 \mathrm{C}$ ).

\section{OA-induced vascular smooth muscle foam cell formation is CD36-dependent}

When rat SMCs were incubated with OA $(250 \mu \mathrm{mol} / \mathrm{L})$ plus CD36 inhibitor sulfo-N-succinimidyl oleate (SSO), cellular lipid inclusions were significantly decreased compared with cells treated only with OA (Figure 2A). Biochemical measurements were consistent with the Oil Red O staining results; compared with the OA-treated SMCs, intracellular triglyceride levels were significantly reduced in cells treated with OA plus SSD $(p<0.01$, Figure 2B). However, SSD did not affect intracellular cholesterol ester levels in cells treated with OA (Figure 2C). Additionally, intracellular triglyceride and cholesterol ester content remained constant in the SMCs treated with SSO only (data not shown). These results suggested that OA-induced vascular smooth muscle foam cell formation is CD36-dependent. Furthermore, the protein level of CD36 in vascular SMCs was not affected by either OA or SSO (Figure 2D). Similarly, neither OA nor SSO influenced the mRNA level of CD36 in vascular SMCs (Figure 2E).

\section{OA modulates vascular SMC phenotype}

We determined the protein and mRNA levels of smooth muscle $\alpha$-actin (SM $\alpha \mathrm{A}$, a marker of undifferentiated proliferating vascular SMCs) and embryonic smooth muscle myosin heavy chain (SMemb, a marker of undifferentiated proliferating vascular SMCs) in cultured vascular SMCs using immunofluorescence analysis. The protein expression of SM $\alpha$ A was downregulated while SMemb was upregulated in vascular SMCs treated with $\mathrm{OA}$ at a concentration of $250 \mu \mathrm{mol} / \mathrm{L}$ (both $p<0.01$, Figure $3 \mathrm{~A}$ and $3 \mathrm{~B})$. However, treatment with SSO significantly attenuated OA-induced changes in the expression of SM $\alpha \mathrm{A}$ and SMemb (both $p<0.05$, Figure 3A and $3 \mathrm{~B})$.

\section{OA enhances atherosclerotic lesion development}

Oil Red $\mathrm{O}$ stained sections of the aortic root from ApoE $^{-/-}$mice fed with normal chow (NC) or OA showed that OA-fed mice had increased lesion area compared to $\mathrm{NC}$-fed mice $\left(2.23 \pm 0.06 \times 10^{5} \mu \mathrm{m}^{2}\right.$ vs. $3.09 \pm 0.10 \times 10^{5}$ $\mu \mathrm{m}^{2}, p<0.01$, Figure $4 \mathrm{~A}$ and $\left.4 \mathrm{~B}\right)$. This effect was partially reversed by acipimox $\left(\mathrm{OA}: 3.09 \pm 0.10 \times 10^{5} \mu \mathrm{m}^{2}\right.$ vs. $\mathrm{OA}+\mathrm{A}: 2.60 \pm 0.10 \times 10^{5} \mu \mathrm{m}^{2}, p<0.05$, Figure $4 \mathrm{~A}$ and $4 \mathrm{~B})$. In addition, oral administration of acipimox did not influence the atherosclerotic lesion of $\mathrm{ApoE}^{-/-}$ mice fed with $\mathrm{NC}\left(\mathrm{NC}: 2.23 \pm 0.06 \times 10^{5} \mu \mathrm{m}^{2}\right.$ vs. $\mathrm{NC}+\mathrm{A}$ : $2.16 \pm 0.03 \times 10^{5} \mu \mathrm{m}^{2}, p>0.05$, Figure $4 \mathrm{~A}$ and $\left.4 \mathrm{~B}\right)$. In OA-treated $\mathrm{ApoE}^{-/-}$mice, the plasma FFA levels in the fasting state were elevated compared with mice fed with a NC diet $(0.70 \pm 0.04 \mathrm{mmol} / \mathrm{L}$ vs. $0.91 \pm 0.03 \mathrm{mmol} / \mathrm{L}$, $p<0.01$, Figure 4C). OA-induced increases in plasma FFA levels were partially reversed by acipimox (OA: $0.91 \pm 0.03 \mathrm{mmol} / \mathrm{L}$ vs. $\mathrm{OA}+\mathrm{A}: 0.78 \pm 0.03 \mathrm{mmol} / \mathrm{L}, p<$ 0.05, Figure 4C). Additionally, in $\mathrm{ApoE}^{-/-}$mice fed with a NC diet, the level of plasma FFA was also decreased by treatment with acipimox (NC: $0.70 \pm 0.04 \mathrm{mmol} / \mathrm{L}$ vs. $\mathrm{NC}+\mathrm{A}: 0.60 \pm 0.03 \mathrm{mmol} / \mathrm{L}, p<0.05$, Figure $4 \mathrm{C})$.

\section{Discussion}

There are two novel findings in the present study. First, OA induces smooth muscle foam cell formation in a dose dependent manner and enhances atherosclerotic lesion development in $\mathrm{ApoE}^{-/-}$mice. Second, the atherogenic effects of OA are CD36 dependent. These findings suggest that FFA directly causes the formation of vascular SMC derived foam cells and accelerates atherosclerosis through CD36.

There have been a number of recent studies that have demonstrated the existence of SMC derived foam cells 


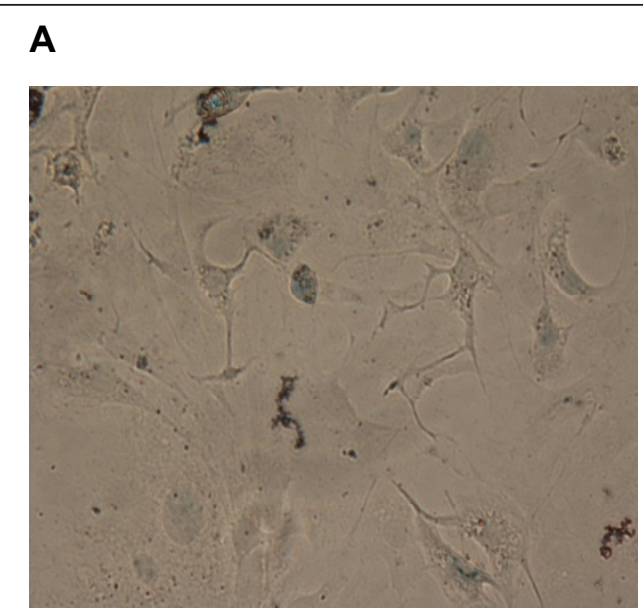

Control

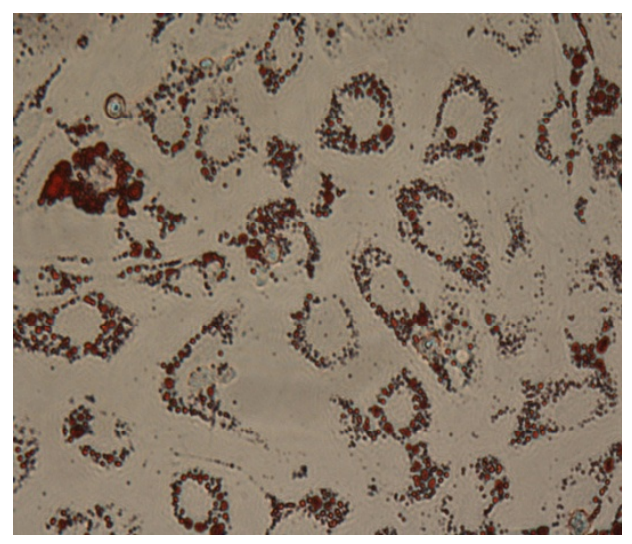

$250 \mu M$ OA

B

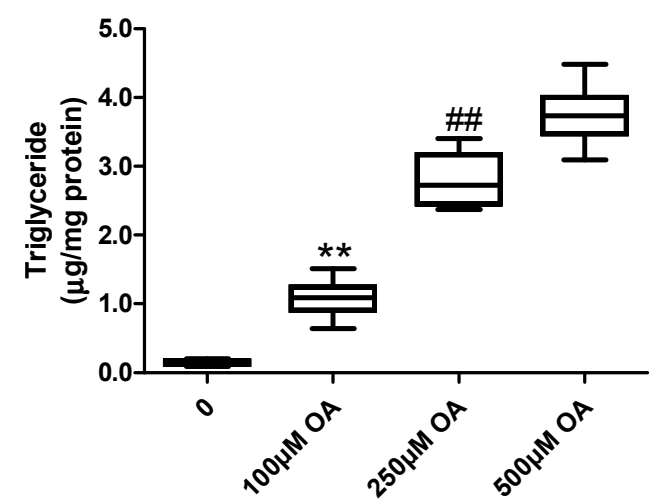

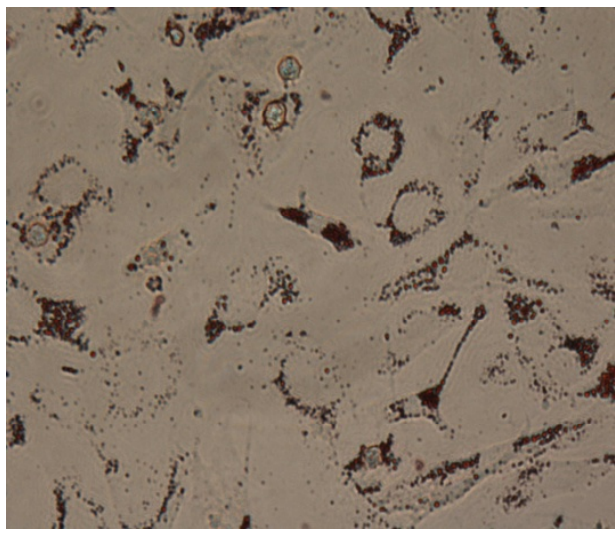

$100 \mu \mathrm{M} O A$

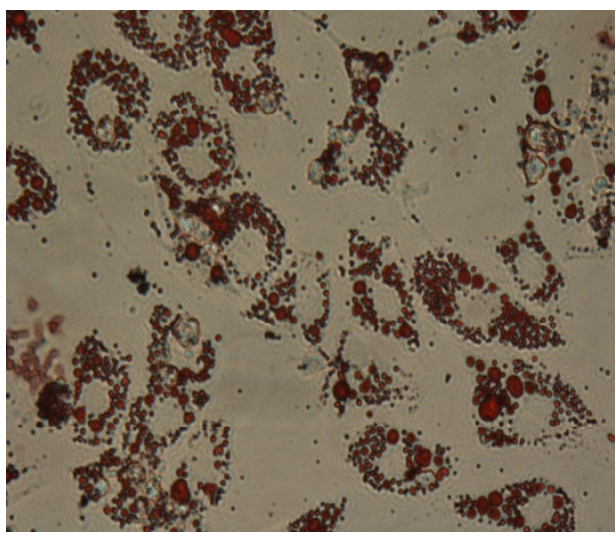

$500 \mu \mathrm{M}$ OA

C

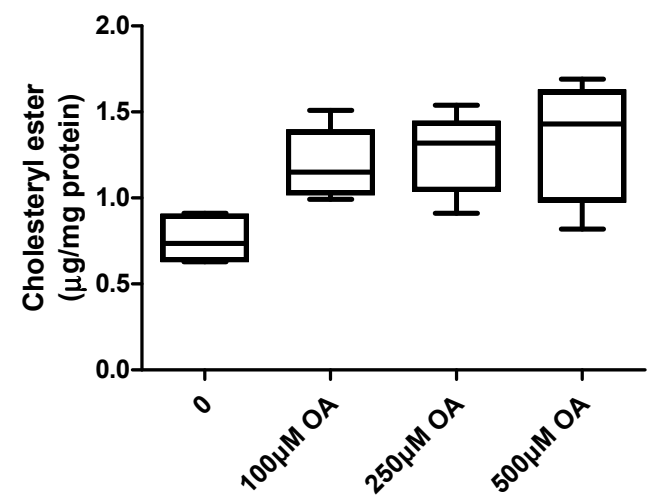

Figure 1 Vascular smooth muscle foam cell formation is induced by OA treatment. (A) Cellular lipid accumulation in rat aortic SMCS after incubation for 48 hours with indicated concentrations of OA. Magnification $\times 400$. Triglyceride (B) and cholesterol ester (C) levels normalized to cellular protein content in rat aortic SMCs. Data are expressed as mean \pm SEM. ${ }^{* *} p<0.01$ compared with the control group, ${ }^{\# \#} p<0.01$ compared with the cells treated with $100 \mu \mathrm{mol} / \mathrm{L}$ of OA. OA, oleic acid; SMCs, smooth muscle cells. 


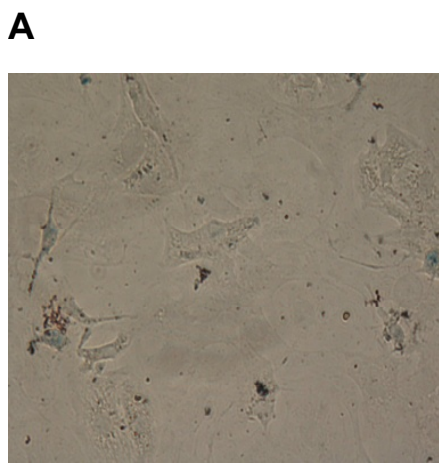

Control

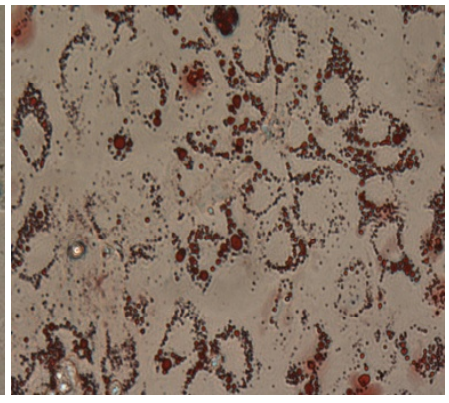

OA

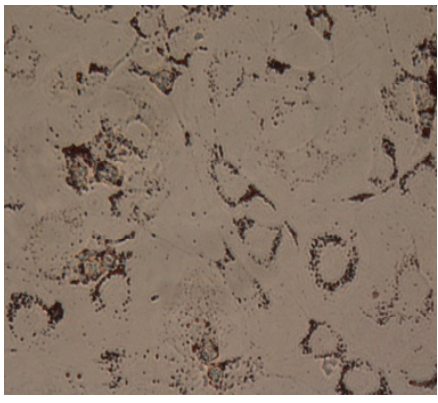

OA+SSO
B

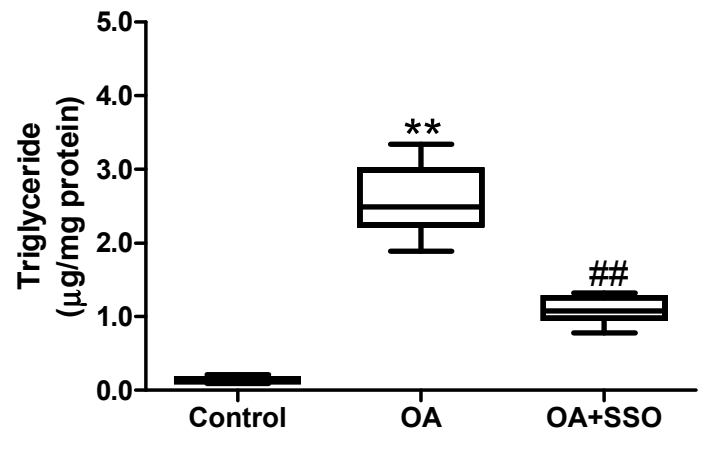

D
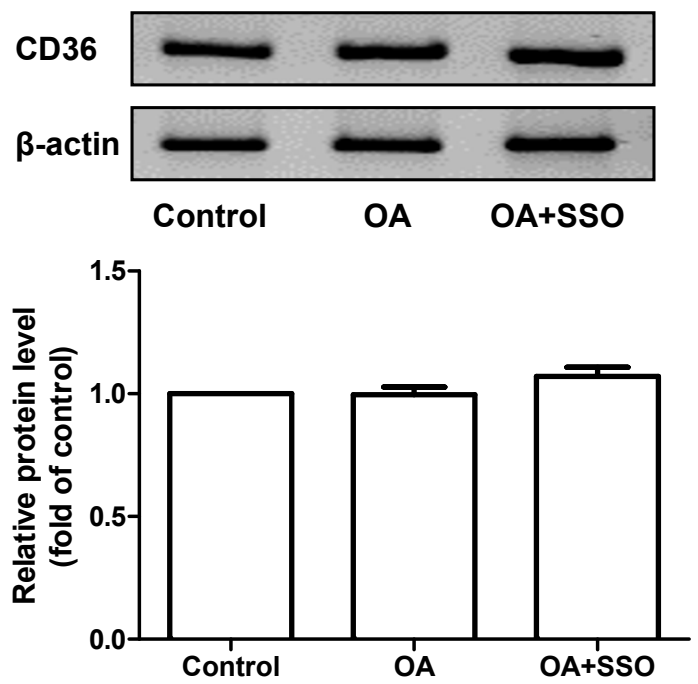

C

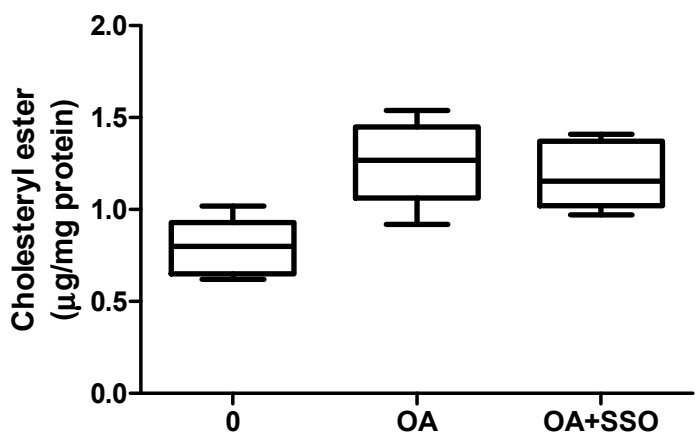

E
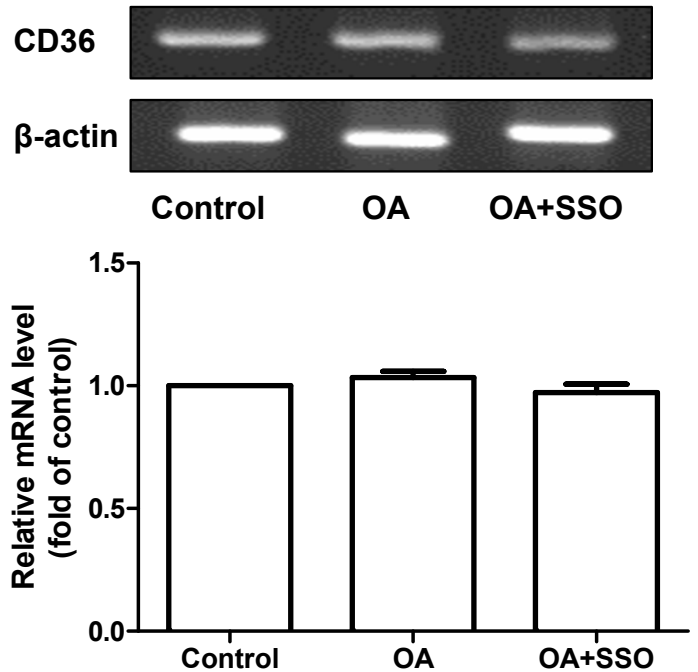

Figure 2 OA-induced foam cell formation is CD36-dependent. (A) Cellular lipid accumulation in rat aortic SMCs after incubation for 48 hours with vehicle (control), OA $(250 \mu \mathrm{mol} / \mathrm{L})$, or OA $(250 \mu \mathrm{mol} / \mathrm{L})$ plus SSO $(250 \mu \mathrm{mol} / \mathrm{L})$. Magnification $\times 400$. Triglyceride (B) and cholesterol ester (C) levels normalized to cellular protein content in rat aortic SMCs. (D) CD36 was determined by western blotting using a specific antibody. Equal protein loading was confirmed using $\beta$-actin antibody. The graph below the blot shows quantification. (E) CD36 was determined by RT-PCR. Equal RNA loading was confirmed using $\beta$-actin primers. The graph below the blot shows quantification. Data are expressed as mean \pm SEM. ${ }^{* *}$ $p<0.01$ compared with the control group, ${ }^{\# \#} p<0.01$ compared with the cells treated with OA alone. OA, oleic acid; SMCs, smooth muscle cells; SSO, sulfosuccinimidyl oleate. 


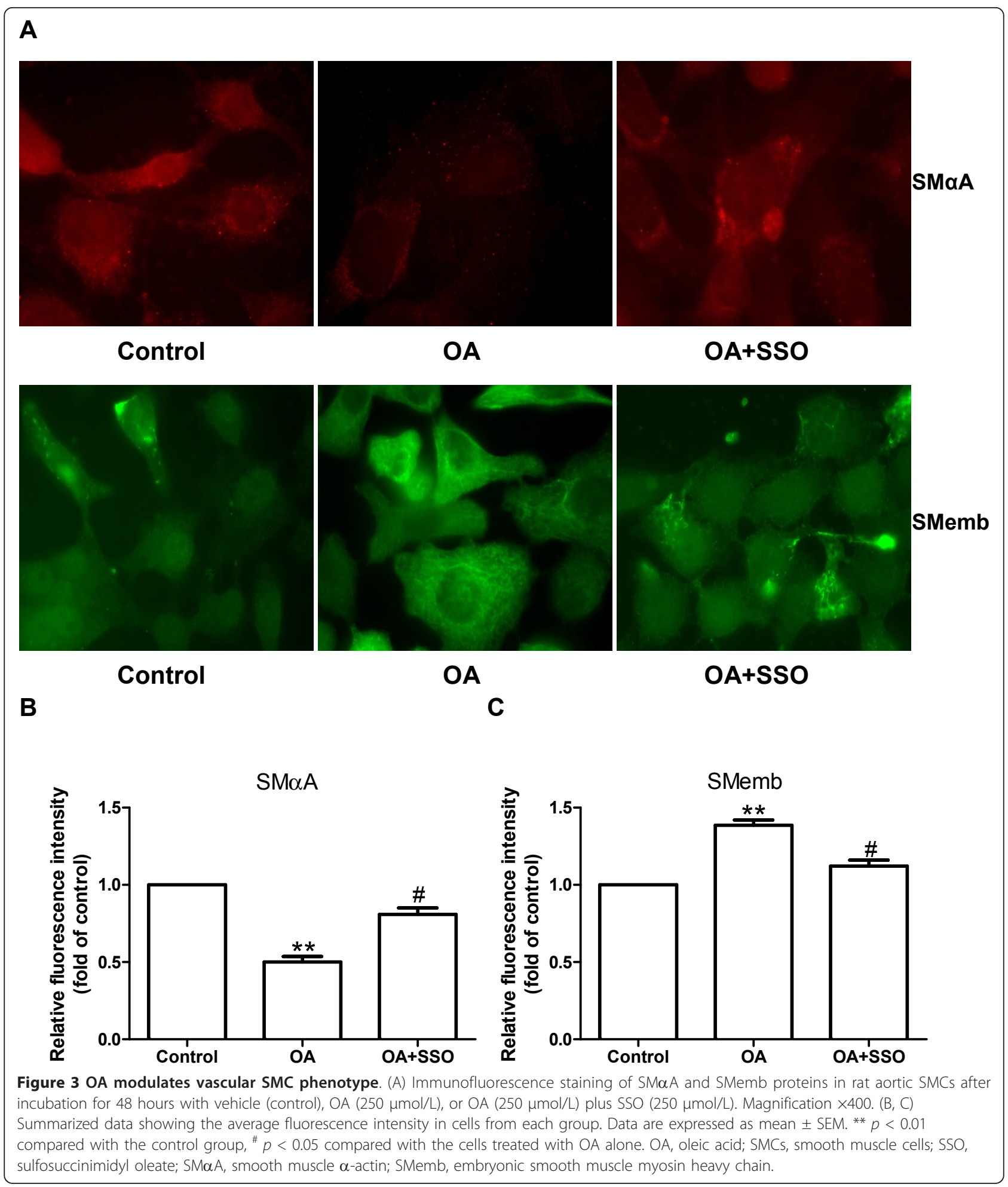

in atherosclerotic lesions [15]. However, the understanding of underlying mechanisms has been very limited [16]. There have been numerous efforts to establish in vitro approaches to induce smooth muscle foam cell formation, but with only limited success [3-5]. Vascular
SMCs accumulate only small amounts of cholesteryl esters when exposed to modified LDL [4]. This failure to overaccumulate cholesteryl esters is due to an LDL-mediated downregulation of cell surface LDL receptors [17]. These results demonstrated that SMCs 


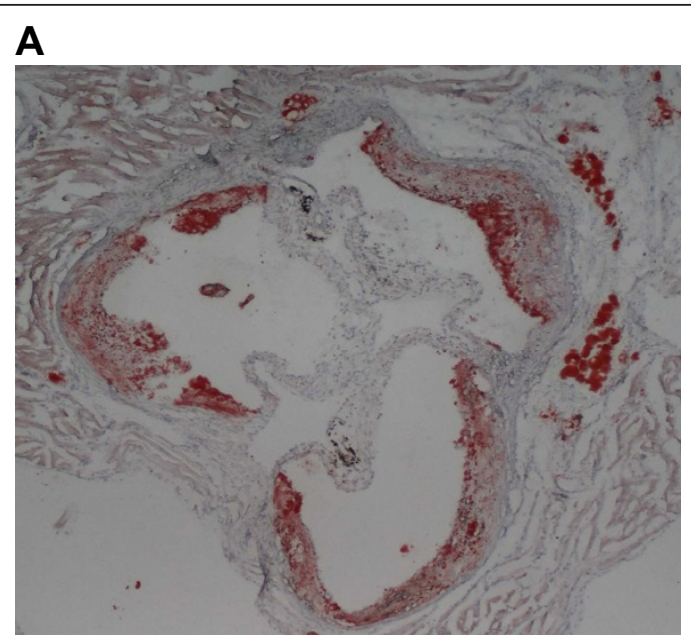

NC

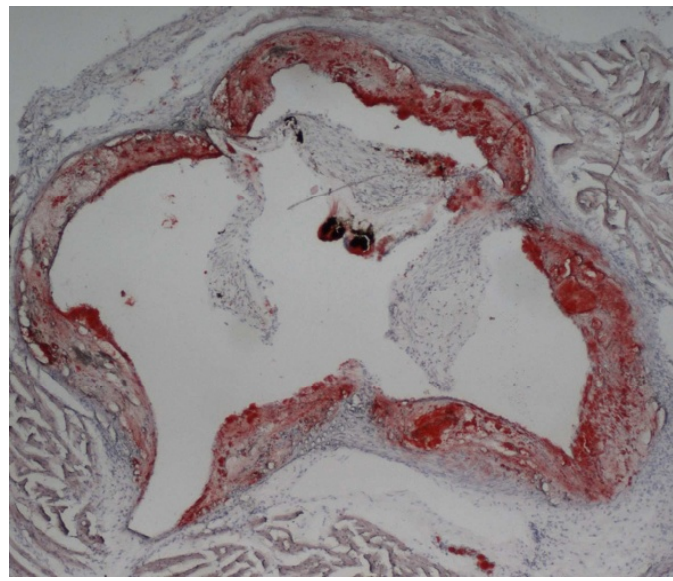

$\mathrm{OA}$

B

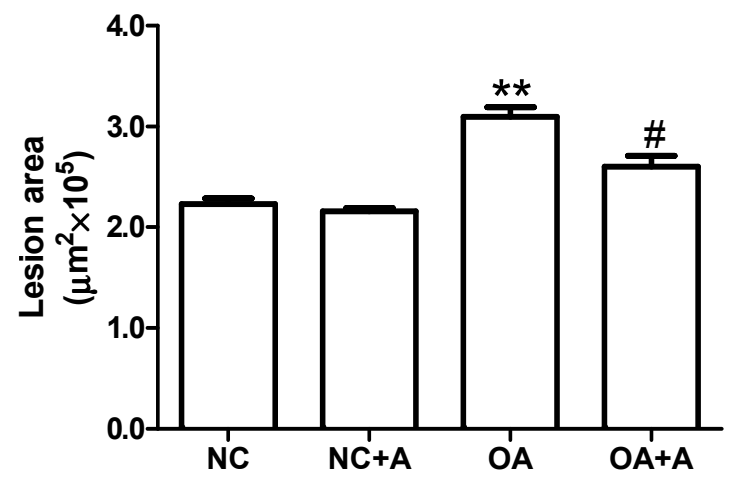

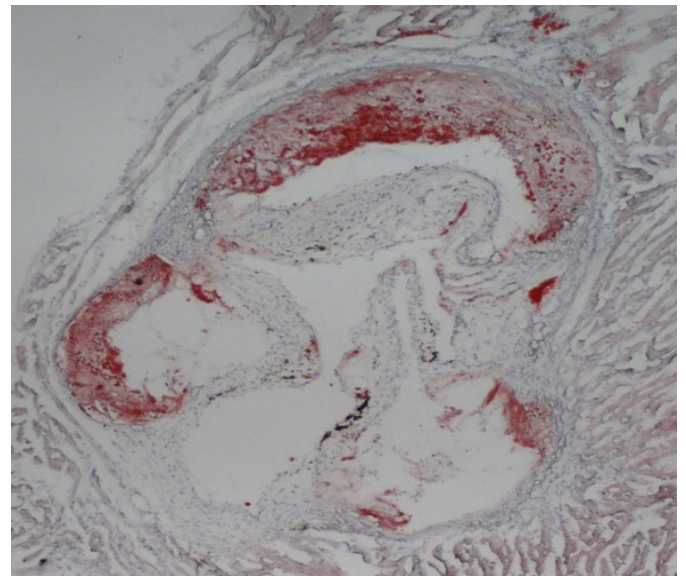

$\mathrm{NC}+\mathrm{A}$

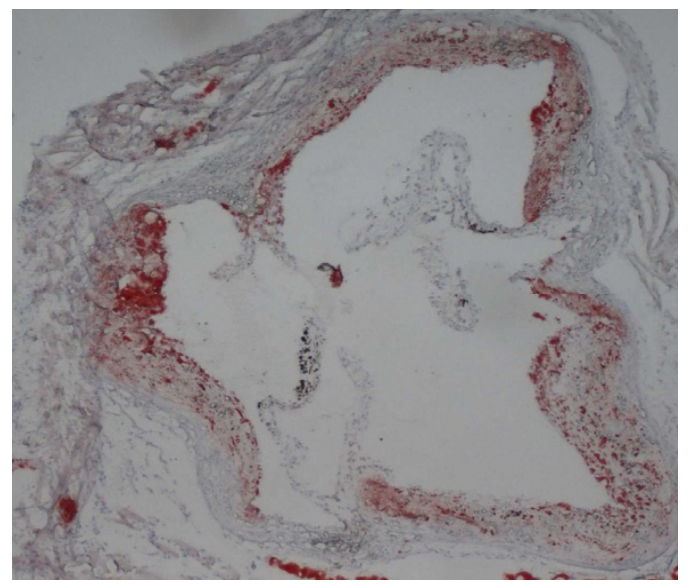

$\mathrm{OA}+\mathrm{A}$

C

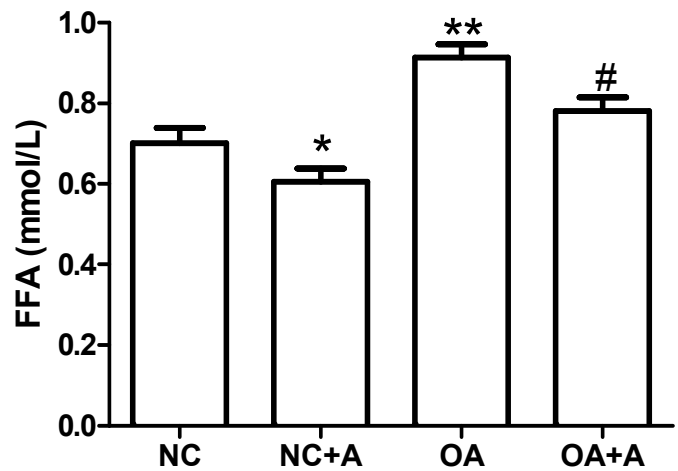

Figure $4 \mathrm{OA}$ enhances atherosclerotic lesion development. (A) Oil Red $\mathrm{O}$ staining of atherosclerotic lesions in the aortic root at the level of the aortic valves. Magnification $\times 40$. (B) Quantitative analyses of the proximal aorta atherosclerotic lesion areas in the normal chow (NC), NC plus acipimox (NC+A), oleic acid $(\mathrm{OA})$ and $\mathrm{OA}$ plus acipimox $(\mathrm{OA}+\mathrm{A})$ groups. (C) Plasma levels of FFA in the four groups. Data are expressed as mean \pm SEM. $n=6$ mice per group. ${ }^{*} p<0.05,{ }^{* *} p<0.01$ compared with the control group, ${ }^{*} p<0.05$ compared with the cells treated with OA alone. NC, normal chow; OA, oleic acid; A, acipimox; FFA, free fatty acid. 
are insensitive to LDL. Using a saturated fatty acid, OA, we successfully reproduced, in vitro, the major biochemical and morphological alterations that occur within SMCs in vivo during atherosclerosis. The current study developed an effective and convenient way to induce the formation of smooth muscle foam cells.

It has been accepted that nonesterified FFA contributes to cardiovascular mortality and is an independent risk factor of atherosclerosis [9]. However, the mechanisms by which FFA causes the development of atherosclerotic lesion are unknown. Previous studies have demonstrated that FFA activates the immune system and promotes a proinflammatory state, which may contribute to its proatherogenic action [18]. The present study provides a direct mechanism by which FFA can deliver significant lipid accumulation to SMCs and induce foam cell formation. The CD36 is one of a number of fatty acid transporters that mediate the uptake of FFA by adipocytes and muscle cells. The current findings provide direct evidence that CD36 is a key determinant of the atherogenic actions of OA. CD36 is not only present on vascular SMCs but also on the surface of monocytes/macrophages. Additionally, CD36 is also involved in uptake of proatherogenic modified forms of LDL. A previous study demonstrated that the absence of CD36 on macrophages may protect against atherosclerosis in ApoE ${ }^{-/-}$mice [19], strongly supporting a pro-atherogenic role for CD36. These results provide new insights into the pro-atherogenic mechanisms of CD36 by mediating the uptake of FFA other than modified LDL uptake. CD36 might become a novel target for the prevention and treatment of atherosclerosis.

We also demonstrated that elevated plasma levels of FFA in $\mathrm{ApoE}^{-/-}$mice can accelerate atherosclerosis, which confirmed the atherogenic action of FFA in vivo. We addressed whether reducing FFA levels ameliorates atherosclerosis. Most FFA in plasma is derived from hydrolysis of adipose tissue triglyceride stores. Acipimox, as an antilipolytic agent, is an effective agent for lowering plasma FFA [20]. We found that acipimox significantly reduced plasma FFA levels and attenuated OA-induced enhancement of atherosclerotic lesions in $\mathrm{ApoE}^{-/-}$mice on an $\mathrm{OA}$ diet. In addition, acipimox remarkably decreased plasma FFA levels in $\mathrm{ApoE}^{-/-}$mice on a NC diet, but did not influence the development of atherosclerotic lesions. This finding suggests that acipimox may ameliorate atherosclerosis by lowing plasma levels of FFA that have been elevated. Therefore, acipimox might become a potent agent for the treatment of atherosclerosis associated with elevated plasma FFA levels.

\section{Conclusions}

In conclusion, the present results demonstrate that $\mathrm{OA}$ induces smooth muscle foam cell formation and enhances atherosclerotic lesion development via CD36.
Moreover, the OA-induced acceleration of atherosclerosis can be reversed by reducing plasma FFA levels using the antilipolytic agent acipimox. The current study also provides a model of smooth muscle foam cells for the study of atherosclerosis. The present findings may contribute to mechanistic insights into fatty acid-induced atherosclerosis.

\section{Methods}

\section{Animal care}

Male Wistar rats, 6 to 8 weeks of age, were obtained from a local animal center. ApoE $E^{-/-}$mice were purchased from the Model Animal Research Center of Nanjing University. Animals were housed under a $12 \mathrm{~h} /$ $12 \mathrm{~h}$ day/night cycle with ad libitum food and water. Experimental procedures were approved by the Hospital Animal Care and Use Committee.

\section{Aortic SMC culture}

Aortic SMCs were obtained from the thoracic aorta of Wistar rats and cultured using previously described tissue explant methods [21]. SMCs were grown in highglucose Dulbecco's modified Eagle's medium (DMEM; Hyclone, Logan, UT, USA) supplemented with $10 \%$ fetal calf serum (FBS; Hyclone, Logan, UT, USA). Cultures were maintained at $37^{\circ} \mathrm{C}$ in a humidified atmosphere of $95 \%$ air/5\% $\mathrm{CO}_{2}$. The smooth muscle phenotype of cultured cells was verified by positive immunofluorescence for smooth muscle specific $\alpha$-actin.

\section{SSO synthesis}

SSO was synthesized according to the method reported earlier by Isenberg et al [22]. $0.25 \mathrm{mmol}$ of OA, $0.25 \mathrm{mmol}$ of $\mathrm{N}$-hydroxysulfosuccinimide and $0.275 \mathrm{mmol}$ of dicyclohexylcarbodiimide were reacted in $0.5 \mathrm{~mL}$ anhydrous N, N-dimethylformamide overnight at room temperature. After crystallizing out the dicyclohexylurea, the solution was filtered and chilled. Then, the product was precipitated out of solution by the addition of cold ethyl acetate and dried under vacuum.

\section{Induction of smooth muscle foam cell formation}

Cultured vascular SMCs were plated on cover slides in six-well plates and maintained in culture media until the cells reached 95\% confluence. Experiment 1: The cells were incubated for 48 hours with 0, 100, 250 and $500 \mu \mathrm{mol} / \mathrm{L}$ of OA in DMEM culture medium. After that, the cells were washed with phosphate-buffered saline, fixed with $4 \%$ paraformaldehyde, and stained with Oil Red O, which detects neutral lipids such as cholesteryl esters and triglycerides. Intracellular triglyceride and cholesteryl esters were detected. Experiment 2: The cells were divided into three groups: control (treated with vehicle), OA (treated with $250 \mu \mathrm{mol} / \mathrm{L}$ of $\mathrm{OA}$ ), and 
$\mathrm{OA}+\mathrm{SSO}$ (treated with $250 \mu \mathrm{mol} / \mathrm{L}$ of $\mathrm{OA}$ plus $250 \mu \mathrm{mol} / \mathrm{L}$ of SSO). After incubation for 48 hours, Oil Red $\mathrm{O}$ staining of the cells was performed, and the intracellular triglyceride and cholesteryl esters were measured. The cells were collected for the detection of CD36 expression.

\section{Western blot analysis}

Cell lysate was prepared by lysing the cells with buffer containing 1\% Triton X-100, $150 \mathrm{mM} \mathrm{NaCl}, 1 \mathrm{mM}$ EDTA, $2.5 \mathrm{mM}$ sodium pyrophosphate, $1 \mathrm{mM} \beta$-glycerophosphate, $1 \mathrm{mM} \mathrm{Na} \mathrm{VO}_{4}, 1 \mu \mathrm{g} / \mathrm{mL}$ leupeptin, $1 \mu \mathrm{g} / \mathrm{mL}$ aprotinin, and $20 \mathrm{mM}$ Tris (pH 7.5) [23]. The lysates were centrifuged to remove cell debris. Protein concentration was determined by Bio-Rad protein assay reagent (Bio-Rad Laboratories, USA). Lysate was electrophoretically transferred onto a nitrocellulose membrane and immunoblotted with rabbit anti-rat CD36 IgG (1:500 dilution, monoclonal, Sigma-Aldrich Co., USA). The blots were incubated with a horseradish peroxidase-conjugated secondary antibody (1:1000 dilution, Santa Cruz Biotechnology, USA), and the bound antibody was visualized using a colored reaction. The relative band intensity was quantified by the use of Quantity One software (Bio-Rad). Equal loading of protein was confirmed by measuring $\beta$-actin expression.

\section{Semi-quantitative reverse-transcription-PCR (RT-PCR)}

Total RNA was extracted from cells with Tripure reagent (Roche Diagnostics Corp., Indianapolis, IN, USA) according to manufacturer instructions [24]. Semiquantitative RT-PCR for CD36 was performed as described previously. The primers for rat CD36 mRNA were as follows: 5'-GTG CAA AGA AGG AAA GCC-3' (sense) and 5'-CAT CAC TAC TCC AAC ACC-3' (antisense). The primers for rat $\beta$-actin mRNA were as follows: $5^{\prime}$ GAA GAT CCT GAC CGA GCG TG-3' (sense) and 5'CGT ACT CCT GCT TGC TGA TCC-3' (antisense). Equal loading of RNA was confirmed by measuring $\beta$-actin expression. The PCR products were visualized by electrophoresis in 1\% agarose gel (Bio-Rad, CA, USA) with ethidium bromide $(0.5 \mu \mathrm{g} / \mathrm{ml}$; Sigma, MO, USA).

\section{Immunofluorescence}

Cultured vascular SMCs were rinsed with PBS, fixed with ice-cold acetone for 15 minutes, incubated in blocking solution (10\% FBS) for 20 minutes at room temperature, and incubated with rabbit anti-SM $\alpha \mathrm{A}$ or rabbit anti-SMemb (1:200 dilution, Santa Cruz Biotechnology, USA) overnight at $4^{\circ} \mathrm{C}$. The cells were washed and incubated with antibody conjugated to a fluorescent probe (rhodamine-conjugated goat anti-rabbit IgG or FITC-conjugated goat anti-rabbit IgG) (1:100 dilution, Santa Cruz Biotechnology, USA) for $30 \mathrm{~min}$ at room temperature. After removing the unbound secondary antibodies by washing the preparations with PBS, imaging was performed using a fluorescence microscope (Nikon TE2000, USA).

\section{Animal treatment}

Male ApoE ${ }^{-1-}$ mice, 6 to 8 weeks of age, were randomized to the $\mathrm{NC}, \mathrm{OA}$, or OA plus lipolysis inhibitor acipimox $(\mathrm{OA}+\mathrm{A})$ groups. OA diet contains $10 \%$ oil. Mice in $\mathrm{OA}+\mathrm{A}$ group were fed $\mathrm{OA}$ diet and treated by oral gavage with $20 \mathrm{mg} / \mathrm{kg} /$ day of acipimox. The administration period lasted 4 weeks.

\section{Assessment of atherosclerosis}

The heart with aorta was fixed overnight in paraformaldehyde and then embedded in optimal cutting temperature cryosectioning medium. Atherosclerotic fatty streak lesions in the aortic root were analyzed using Oil Red O staining and were counterstained with hematoxylin [25]. Atherosclerotic lesions were captured as digital images by a color camera attached to a microscope (Nikon TE2000, USA), and total mean lesion area was quantified using image analysis software.

\section{Plasma FFA level measurement}

Fasting blood samples were obtained and plasma FFA was determined by a microplate enzymatic assay using a commercially available kit (Jiancheng Bioengineering Institute, Nanjing, China). The measurements were performed according to manufacturer guidelines.

\section{Statistical analysis}

Continuous data are presented as mean \pm SEM. Comparisons between groups were determined by one-way ANOVA with a post hoc Student's t-test (SPSS Inc., Chicago, IL). Probabilities of $p<0.05$ were considered statistically significant.

\section{List of abbreviations}

FFA: free fatty acid; FAT/CD36: fatty acid translocase; SMCs: smooth muscle cells; OA: oleic acid; NC: normal chow; LDL: low density lipoprotein; SSO: sulfo-N-succinimidyl oleate; SMaA: smooth muscle a-actin; SMemb: embryonic smooth muscle myosin heavy chain.

\section{Acknowledgements}

This study was supported by grants from the Medical Scientific Research Program of PLA Chengdu Military Area Command during the $11^{\text {th }}$ Five-Year Plan Period (No. MB09023) and Science \& Technology Project of Sichuan Province (No. 2010JY0028).

\section{Authors' contributions}

SM carried out the animal studies and drafted the manuscript. DY carried out the cell studies. DL participated in the molecular studies. BT participated in the design of the study and performed the statistical analysis. YY conceived of the study, and participated in its design and coordination and helped to draft the manuscript. All authors read and approved the final manuscript. 


\section{Competing interests}

The authors declare that they have no competing interests.

Received: 25 February 2011 Accepted: 12 April 2011

Published: 12 April 2011

\section{References}

1. Siegel-Axel D, Daub K, Seizer P, Lindemann S, Gawaz M: Platelet lipoprotein interplay: trigger of foam cell formation and driver of atherosclerosis. Cardiovasc Res 2008, 78:8-17.

2. Doran AC, Meller N, McNamara CA: Role of smooth muscle cells in the initiation and early progression of atherosclerosis. Arterioscler Thromb Vasc Biol 2008, 28:812-819.

3. Klouche M, Rose-John S, Schmiedt W, Bhakdi S: Enzymatically degraded, nonoxidized LDL induces human vascular smooth muscle cell activation, foam cell transformation, and proliferation. Circulation 2000, 101:1799-1805.

4. Wada Y, Sugiyama A, Yamamoto T, Naito M, Noguchi N, Yokoyama S, Tsujita M, Kawabe Y, Kobayashi M, Izumi A, et al: Lipid accumulation in smooth muscle cells under LDL loading is independent of LDL receptor pathway and enhanced by hypoxic conditions. Arterioscler Thromb Vasc Biol 2002, 22:1712-1719.

5. Wolfbauer G, Glick JM, Minor LK, Rothblat GH: Development of the smooth muscle foam cell: uptake of macrophage lipid inclusions. Proc Natl Acad Sci USA 1986, 83:7760-7764.

6. Pomerantz KB, Summers B, Hajjar DP: Eicosanoid metabolism in cholesterol-enriched arterial smooth muscle cells. Evidence for reduced posttranscriptional processing of cyclooxygenase I and reduced cyclooxygenase II gene expression. Biochemistry 1993, 32:13624-13635.

7. Pilz S, Scharnagl H, Tiran B, Seelhorst U, Wellnitz B, Boehm BO, Schaefer JR, Marz W: Free fatty acids are independently associated with all-cause and cardiovascular mortality in subjects with coronary artery disease. J Clin Endocrinol Metab 2006, 91:2542-2547.

8. Pirro M, Mauriege P, Tchernof A, Cantin B, Dagenais GR, Despres JP, Lamarche B: Plasma free fatty acid levels and the risk of ischemic heart disease in men: prospective results from the Quebec Cardiovascular Study. Atherosclerosis 2002, 160:377-384.

9. Smith SR, Wilson PW: Free fatty acids and atherosclerosis-guilty or innocent? J Clin Endocrinol Metab 2006, 91:2506-2508.

10. Hua J, Ma X, Webb T, Potter JJ, Oelke M, Li Z: Dietary fatty acids modulate antigen presentation to hepatic NKT cells in nonalcoholic fatty liver disease. J Lipid Res 2010, 51:1696-1703.

11. Andersson A, Nalsen C, Tengblad S, Vessby B: Fatty acid composition of skeletal muscle reflects dietary fat composition in humans. Am J Clin Nutr 2002, 76:1222-1229.

12. Collot-Teixeira S, Martin J, McDermott-Roe C, Poston R, McGregor JL: CD36 and macrophages in atherosclerosis. Cardiovasc Res 2007, 75:468-477.

13. Kwok CF, Juan CC, Ho LT: Endothelin-1 decreases CD36 protein expression in vascular smooth muscle cells. Am J Physiol Endocrinol Metab 2007, 292:E648-652.

14. Carley AN, Kleinfeld AM: Fatty acid (FFA) transport in cardiomyocytes revealed by imaging unbound FFA is mediated by an FFA pump modulated by the CD36 protein. J Biol Chem 2011, 286:4589-4597.

15. Rong JX, Kusunoki J, Oelkers P, Sturley SL, Fisher EA: Acyl-coenzymeA (CoA):cholesterol acyltransferase inhibition in rat and human aortic smooth muscle cells is nontoxic and retards foam cell formation. Arterioscler Thromb Vasc Biol 2005, 25:122-127.

16. Lim HJ, Lee S, Lee KS, Park JH, Jang Y, Lee EJ, Park HY: PPARgamma activation induces CD36 expression and stimulates foam cell like changes in rVSMCs. Prostaglandins Other Lipid Mediat 2006, 80:165-174.

17. Goldstein JL, Anderson RG, Buja LM, Basu SK, Brown MS: Overloading human aortic smooth muscle cells with low density lipoproteincholesteryl esters reproduces features of atherosclerosis in vitro. $J$ Clin Invest 1977, 59:1196-1202.

18. Tripathy D, Mohanty P, Dhindsa S, Syed T, Ghanim H, Aljada A, Dandona P: Elevation of free fatty acids induces inflammation and impairs vascular reactivity in healthy subjects. Diabetes 2003, 52:2882-2887.

19. Schneider JG, Yang Z, Chakravarthy MV, Lodhi IJ, Wei X, Turk J, Semenkovich CF: Macrophage fatty-acid synthase deficiency decreases diet-induced atherosclerosis. J Biol Chem 2010, 285:23398-23409.
20. Guo W, Wong S, Pudney J, Jasuja R, Hua N, Jiang L, Miller A, Hruz PW Hamilton JA, Bhasin S: Acipimox, an inhibitor of lipolysis, attenuates atherogenesis in LDLR-null mice treated with HIV protease inhibitor ritonavir. Arterioscler Thromb Vasc Biol 2009, 29:2028-2032.

21. Tang B, Ma ST, Yang YJ, Yang DC, Chen JS, Su XH, Tan Y, Sun MQ, Li D: Overexpression of angiotensin II type 2 receptor suppresses neointimal hyperplasia in a rat carotid arterial balloon injury model. mol Med Rep 2011, 4:249-254.

22. Isenberg JS, Jia Y, Fukuyama J, Switzer CH, Wink DA, Roberts DD: Thrombospondin-1 inhibits nitric oxide signaling via CD36 by inhibiting myristic acid uptake. J Biol Chem 2007, 282:15404-15415.

23. Yang D, Ma S, Li D, Tang B, Yang Y: Angiotensin II receptor blockade improves matrix metalloproteinases/tissue inhibitor of matrix metalloproteinase- 1 balance and restores fibronectin expression in rat infarcted myocardium. Biochem Biophys Res Commun 2009, 388:606-611.

24. Yang D, Ma S, Tan Y, Li D, Tang B, Zhang X, Sun M, Yang Y: Increased expression of calpain and elevated activity of calcineurin in the myocardium of patients with congestive heart failure. Int J Mol Med 2010, 26:159-164.

25. Furuhashi M, Tuncman G, Gorgun CZ, Makowski L, Atsumi G, Vaillancourt E, Kono K, Babaev VR, Fazio S, Linton MF, et al: Treatment of diabetes and atherosclerosis by inhibiting fatty-acid-binding protein aP2. Nature 2007, 447:959-965.

\section{doi:10.1186/1476-511X-10-53}

Cite this article as: Ma et al:: Oleic acid induces smooth muscle foam cell formation and enhances atherosclerotic lesion development via CD36. Lipids in Health and Disease 2011 10:53.

\section{Submit your next manuscript to BioMed Central and take full advantage of:}

- Convenient online submission

- Thorough peer review

- No space constraints or color figure charges

- Immediate publication on acceptance

- Inclusion in PubMed, CAS, Scopus and Google Scholar

- Research which is freely available for redistribution
C Biomed Central 